\title{
Dipyrone, scopolamine, and meloxicam for conventional or two-port laparoscopic-assisted ovariohysterectomy in female $\operatorname{dogs}{ }^{1}$
}

\section{Dipirona, escopolamina e meloxicam após ovário-histerectomia convencional ou videoassistida por dois portais em fêmeas caninas}

\author{
Fabíola Dalmolin ${ }^{2 *}$; Marília Teresa Oliveira ${ }^{3}$; Saulo Tadeu Lemos Pinto Filho ${ }^{4}$; \\ Marcos André Braz Vaz ${ }^{5}$; Bianca Santana de $\mathrm{Cecco}^{6}$; João Pedro Scussel Feranti ${ }^{7}$; \\ Elizabeth Regina Carvalho ${ }^{8}$; Marco Augusto Machado Silva'; \\ Maurício Veloso Brun ${ }^{10}$
}

\section{Highlights:}

The proposed protocol was efficient to control pain after both OVH techniques.

Minimal pain scale difference was observed between surgical techniques.

It was observed vomiting in two animals submitted to conventional surgery.

Animals underwent to video surgery ate before dogs submitted to conventional OHV.

\begin{abstract}
For ethical and organic reasons, surgical and analgesic techniques that minimize and adequately control pain should be studied. Ovariohysterectomy is the most common surgical technique in veterinary medicine and is performed in female dogs for elective or therapeutic purposes. Both conventional and minimally invasive surgical techniques are used in veterinary medicine; however, the minimally invasive laparoscopic technique is considered superior to the conventional technique because it is associated with a less painful and faster post-operative recovery. However, for various reasons, the laparoscopic technique is not yet widely used in veterinary medicine, and the conventional ovariohysterectomy is still the most common. The aim of this study, therefore, was to validate the efficacy of the combination of dipyrone, scopolamine, and meloxicam after conventional or two-port laparoscopic-assisted ovariohysterectomies in female dogs. Additionally, this study sought to assess recovery after the two surgical modalities while receiving the same analgesic protocol. Fourteen healthy adult female dogs were spayed and then evaluated using the Visual Analogue Scale, the Melbourne Scale, and the short
\end{abstract}

\footnotetext{
1 Parte da Tese apresentada ao Programa de Pós-graduação em Medicina Veterinária, PPGMV, Universidade Federal de Santa Maria, UFSM, Santa Maria, RS, Brasil.

2 Prof $^{a}$ Dra $^{\mathrm{a}}$, Programa de Pós-Graduação em Saúde, Bem-Estar e Produção Animal Sustentável, PPG/SBPAS, Universidade Federal da Fronteira Sul Campus Realeza, UFFS, Realeza, PR, Brasil. E-mail: fabiola.dalmolin@uffs.edu.br

3 Prof $^{\mathrm{a}} \mathrm{Dr}^{\mathrm{a}}$, Universidade Federal do Pampa, UNIPAMPA, Campus Uruguaiana, Uruguaiana, RS, Brasil. marilia2805@hotmail. com

4 Prof. Dr., PPGMV, UFSM, Santa Maria, RS, Brasil. E-mail: saulovet2011@hotmail.com

5 Prof. Dr., Universidade Federal do Amazonas, Manaus, AM, Brasil. E-mail: brazvaz@yahoo.com.br

6 Discente de Doutorado, Programa de Pós-Graduação em Medicina Veterinária, Universidade Federal do Rio Grande do Sul, UFRGS, Porto Alegre, RS. E-mail: biasantanacecco@gmail.com

7 Prof. Dr., Universidade da Região da Campanha, Campus Alegrete, Alegrete, RS, Brasil. E-mail: johny.sf@hotmail.com

8 Médica Veterinária Autônoma, Dr ${ }^{\mathrm{a}}$ em Medicina Veterinária, Alegre, ES, Brasil. E-mail: beth_rcarvalho@hotmail.com

9 Prof. Dr., Universidade Federal de Goiás, UFG, Goiânia, GO, Brasil. E-mail: silvamam@gmail.com

${ }^{10}$ Prof. Dr. PPGMV, UFSM, Santa Maria, RS, Brasil. Researcher CNPq - Brasil 305876/2018-0. E-mail: mauriciovelosobrun@ hotmail.com

* Author for correspondence
} 
form of the Glasgow Composite Measure Pain Scale for 72 hours after surgery. The analgesic protocol was efficient for pain control after both techniques, with minimal differences between the groups.

Key words: Celiotomy. Laparoscopy. Metamizol. Pain control. Videosurgery.

\section{Resumo}

Devido a razões éticas e orgânicas, técnicas cirúrgicas e analgésicas que minimizam e controlam adequadamente a dor devem estudadas. A ovário-histerectomia é a técnica cirúrgica mais realizada em medicina veterinária, seja aplicada com fins eletivos ou terapêuticos. As técnicas cirúrgicas convencionais e minimamente invasivas são utilizadas em medicina veterinária, e as laparoscópicas são consideradas superiores, pois promovem menor dor e mais rápida recuperação pós-operatória. Embora esta modalidade cirúrgica seja considerada superior, por diferentes razões ainda não é tão difundida na medicina veterinária, sendo a técnica convencional de ovário-histerectomia a mais utilizada em cadelas. Por estas razões, o objetivo deste estudo foi validar a eficácia do protocolo dipirona, escopolamina e meloxicam em cadelas submetidas a ovário-histerectomia convencional ou videoassistida por dois portais, assim como avaliar a recuperação dos animais submetidos a duas modalidades cirúrgicas junto ao referido protocolo analgésico. Assim, 14 cadelas adultas saudáveis foram submetidas a ováriohisterectomia e avaliadas por meio da Escala Visual Analógica, Escala de Melbourne e Forma reduzida da Escala Composta de Glasgow até 72 horas após a realização do procedimento cirúrgico. O protocolo analgésico foi eficiente para controle da dor nos animais submetidos a ambas as técnicas cirúrgicas, e mínimas diferenças foram observadas entre os grupos.

Palavras-chave: Celiotomia. Controle de dor. Dipirona. Laparoscopia. Videocirurgia.

\section{Introduction}

The International Association for the Study of Pain defined pain as "an unpleasant sensory and emotional experience associated with actual or potential tissue damage or described in terms of such damage" (Wiese, 2014). Mechanical or thermal stimuli with sufficient intensity to result in tissue injury triggers physical responses including the withdrawal of the affected body part, changes in the autonomic outflow, and activation of the hypothalamic pituitary axis, causing an increased concentration of circulating stress hormones (Wiese, 2014). Uncontrolled pain in veterinary patients can result in unwanted complications, including cardiovascular stress, immunosuppression, anorexia, and cachexia (Hancock et al., 2005).

The main pharmacological treatments used for acute pain are opioids and non-opioids, which include non-steroidal anti-inflammatories (NSAIDs) and antipyretics (Imagawa et al., 2011). Sodium dipyrone, or metamizol, reduces pain by inhibiting prostaglandin synthesis in the peripheral and central nervous system (Chandrasekharan, Dai, Roos, \& Evanson, 2002). N-butylscopolamine bromide treats colic by acting on smooth abdominal and pelvic muscles and affecting their intramural parasympathetic ganglia (Ganem et al., 2005). Meloxicam is a predominantly $\mathrm{COX}-2$ selective NSAID. NSAIDs primarily act by inhibiting the COX-2 isoform and can function as an analgesic and anti-inflammatory without adverse effects on renal, gastric, or platelet function (Caulkett, Read, Fowler, \& Waldnert, 2003).

Ovariohysterectomies (OVH) is a common surgical procedure performed in small animal practices. The traditional OVH technique involves a resection of the ovaries and uterus through a median celiotomy (Macphail \& Fossum, 2019). However, reports of minimally invasive $\mathrm{OVH}$ techniques in dogs have been available since the nineties (Brun, 2015), these procedures present advantages such as less postoperative pain, decreased risk of dehiscence and hemorrhage, and a decreased convalescence period (Linhares et al., 2019). 
Although studies have compared female dogs' pain after conventional $\mathrm{OVH}$ to that after laparoscopic $\mathrm{OVH}$, literature addressing the efficacy of a combination of dipyrone, scopolamine, and meloxicam after OVH is sparse. Therefore, the purpose of this study was to validate the efficacy of the combination of dipyrone, scopolamine, and meloxicam after both conventional and two-port laparoscopic-assisted OVHs in female dogs through utilizing three different scales for pain assessment, assessing the recovery of the animals after the two procedures, and examining the referenced analgesic protocol.

\section{Materials and Methods}

Institutional review board approval of animal housing and experimental protocols was granted by the Committee of Ethics and Animal Use of the University where the study was performed. Fourteen adult mongrel female dogs aged 1-4 years, weighing $16.19 \pm 3.73 \mathrm{~kg}$, and considered healthy based on clinical examination and laboratory assessment (complete blood count, serum creatinine, albumin, alkaline phosphatase, and alanine aminotransferase) were recruited for this study. Animals arrived at the hospital $48 \mathrm{~h}$ prior to the surgery and immediately received $1 \mathrm{mg} / \mathrm{kg}^{-1}$ nitenpyram orally (Capstar, Novartis, Brazil). Patients received water and commercial dog food ad libitum and were housed in an acclimatized environment $\left(22^{\circ} \mathrm{C}\right)$. During this time, they only had contact with the researchers and the other animals involved in the study.

After fasting (12 h for food and $8 \mathrm{~h}$ for water), a physical examination was performed, and a wide trichotomy of the abdomen was performed. Groups were formed at random according to the surgical technique: the two-port laparoscopicassisted OVH (GV) and the celiotomy group (GC). All animals received acepromazine (0.05 $\mathrm{mg} / \mathrm{kg}^{-1}$ intramuscularly (IM)) (Acepran $0.2 \%$, Univet, Brazil). Approximately $10 \mathrm{~min}$ later, venous access was obtained, Ringer's lactate solution (10 $\mathrm{mL} / \mathrm{kg}^{-1} / \mathrm{h}^{-1}$, intravascularly (IV)) was started, and anesthesia was induced with propofol (4 mg/ $\mathrm{kg}^{-1} \mathrm{IV}$ ) (Fresofol, FrenesiusKabi, Brazil). After tracheal intubation, general anesthesia was maintained with isoflurane in $100 \%$ oxygen, adjusted to keep the patients on an adequate anesthetic plane (palpebral reflexes absent, corneal reflex present, and rotated eyeballs) and spontaneously breathing. Immediately after intubation, a loading dose of fentanyl (Fentanest, Cristalia, Brazil) was administered $\left(1.25 \mu \mathrm{g} / \mathrm{kg}^{-1}\right.$, IV, over $5 \mathrm{~min}$ ) followed by a constant rate infusion (CRI) at $15 \mu \mathrm{g} / \mathrm{kg}^{-1} / \mathrm{h}^{-1}$ through a peristaltic infusion pump (CELM, Brazil). For antibiotic prophylaxis, sodium ampicillin (20 mg/ $\mathrm{kg}^{-1}$, IV) (Amplatil, Novafarma, Brazil) was used.

A single surgeon who was proficient in both surgical techniques performed all surgical procedures. A standard retro-umbilical celiotomy encompassing one-third of the distance between the umbilicus and the pubis was performed for the conventional OVH (GC group). In the GV group, surgical access was achieved using two $11 \mathrm{~mm}$ ports, which were inserted through the umbilicus and in the pre-pubic area (Brun, 2015). In the GC group, hemostasis of the ovarian pedicles and uterine body vessels was performed using double ligatures (2-0 polyglactin 910, according to the modified three-clamp technique after manual rupture of the suspensory ligament) (Macphail \& Fossum, 2019). In the GV group, bipolar cauterization and a transection of the ovarian pedicles and suspensory ligament was performed (Lina Tripol Powerblade, Lina Medical Inc., Denmark), and double ligatures were applied to the uterine body and vessels using the same thread. At the end of the procedure, patients received the combined formulation of IV dipyrone $\left(25 \mathrm{mg} / \mathrm{kg}^{-1}\right)$ and scopolamine $(0.2 \mathrm{mg} /$ $\left.\mathrm{kg}^{-1}\right)$, and meloxicam $\left(0.2 \mathrm{mg} / \mathrm{kg}^{-1}\right)$. Subsequent doses of dipyrone-scopolamine were given 4 times a day and meloxicam was given once a day, both subcutaneously, providing $48 \mathrm{~h}$ analgesia. Surgical time was measured in minutes in both groups.

Three trained evaluators, who were blinded to the surgical technique and analgesic protocol, 
carried out the pain assessments. The abdomen was widely clipped, and the region was covered by sterile surgical sponges, bandages, and an elastic sheath in order to keep the evaluators from determining the surgical technique. Before pain assessments, a technician checked that the dressings were in place and changed them if necessary.

Postoperative pain was assessed using the Visual Analogue Scale (VAS), the University of Melbourne Pain Scale (UMPS), and the short form of the Glasgow Composite Measure Pain Scale (CMPS$\mathrm{SF}$ ). Each evaluator performed their assessment individually, at the same time, but without influencing each other. The arithmetic mean of all the evaluators' pain assessment scores was used as the final score. The evaluation sessions began with the opening of the cage, first observing the patient's exit from the cage and then through gently palpating the ventral abdominal area. Rescue analgesics were predicted when $30 \%$ of the maximum scores on the scales were obtained. Rescue analgesia using morphine sulfate $\left(0.5 \mathrm{mg} / \mathrm{kg}^{-1}, \mathrm{IM}\right)$ was used if 2 or more evaluators recorded $50 \mathrm{~mm}$ on the VAS, 7 points on the UMPS, or 12 points on the CMPS-SF. Pain assessment began $120 \mathrm{~min}$ after extubation and was conducted at $2 \mathrm{~h}$ intervals during the first $8 \mathrm{~h}$, and then at $12,18,24,36,48$, and $72 \mathrm{~h}$ after surgery. Food intake and the time to the first defecation were evaluated. The dogs had access to commercial food at each pain evaluation time.

All data were submitted to the Shapiro-Wilk normality test. The pain assessment, time to the first spontaneous food intake, and the first bowel movement were compared using the non-parametric Kruskal-Wallis (within group, across moments) and Mann-Whitney (between groups, at each moment) tests. Medians were compared using the ScottKnott and the Spearman test to investigate the correlation between the pain scores. Agreement among evaluators was measured using the Kappa coefficient. The level of significance was set at $5 \%$ for all tests. Tests were performed using the $\mathrm{R}$ Development Core Team [R] (2018) software.
Agreement among evaluators which was measured using the Kappa coefficient was light $(1 \times 1)$, moderate $(1 \times 3)$, and moderate $(2 \times 3)$. The correlation between scales using the Spearman test $(P<0.05)$ was significant and positive in the VAS $\times$ UMPS $(r=0.30, P<0.01,95 \%$ confidence interval $(\mathrm{CI})=0.51-0.71)$, UMPS $\mathrm{x}$ CMPS-SF $(r=0.33, P$ $<0.01,95 \% \mathrm{CI}=0.83-0.91$ ), and VAS $\times$ CMPS-SF $(r=0.77, P<0.01,95 \% \mathrm{CI}=0.39-0.63)$.

\section{Results and Discussion}

Studies of acute clinical pain have most often evaluated the effects of surgical trauma on pet animals attending veterinary teaching hospitals for surgery. Of these surgical models, dog OVHs appear to be among the most common, possibly because they are a relatively standardized source of soft tissue pain (Hansen, 2003), as was used in this study. Admitting the patients $48 \mathrm{~h}$ prior to surgery allowed for the animal's acclimation to the experimental environment as well as to the researchers, minimizing the effects of stress and manipulation. None of the animals had any significant operative complications, and there was no evidence of hemorrhaging or iatrogenic trauma during surgery. Surgical time was longer in the GV group $(P=0.01, \mathrm{GV}=32.14 \pm 7.96 \mathrm{~min}$ vs $\mathrm{GC}$ $=21.86 \pm 3.71 \mathrm{~min})$, which was similar to other authors' findings (Hancock et al., 2005).

It is difficult to recognize and quantify pain in dogs due to their inability to verbally communicate and the inter-individual variability in pain expression (Kim et al., 2012). It is generally accepted that pain assessments in animals are more accurate when multidimensional or composite ratings are used (Murrell, Psatha, Scott, Reid, \& Hellebrekers, 2008). According to Flôr (2012), several scales have been described for dogs. However, since no scale is considered the gold standard and all of them have faults (Kim et al., 2012), we chose the VAS, UMPS, and CMPS-SF since they include both objective and subjective measurements. 
The VAS is one of the most extensively used subjective pain scoring systems in veterinary medicine. The VAS is a $100-\mathrm{mm}$ line anchored on the left by either the number 0 or wording such as "no pain" and on the right by either the number 100 or wording such as "worst possible pain" or "worst possible pain for this procedure" (Wiese, 2014). The observer places a mark along the line indicating the dog's estimated pain intensity (Rialland et al., 2012). This scale revealed higher scores in both groups at 2 ,
4 , and $6 \mathrm{~h}$ postoperatively, which decreased at 8 and $12 \mathrm{~h}$, considering basal levels. Significant decreases occurred at 24, 36, and $48 \mathrm{~h}$ until baseline values were reached $72 \mathrm{~h}$ postoperatively. According to the VAS, there was no difference between surgical techniques at any time point (Figure 1 and Figure 2 ), and the correlation among the evaluators $1 \times 2$, $2 \times 3$, and $1 \times 3$ was moderate $(r=0.62,0.74$, and 0.66 , respectively) (Santos, 2018).

\begin{tabular}{|c|c|c|c|c|c|c|c|}
\hline \multicolumn{8}{|c|}{ VAS } \\
\hline \multirow{2}{*}{ Times } & \multicolumn{3}{|c|}{ GC } & \multicolumn{3}{|c|}{ GV } & \multirow[b]{2}{*}{ P-value } \\
\hline & $\mathrm{Q}_{1}$ & Median & $\mathrm{Q}_{3}$ & $\mathrm{Q}_{1}$ & Median & $\mathrm{Q}_{3}$ & \\
\hline Basal & 0.00 & $0.00 \mathrm{~d}^{*}$ & 0.00 & 0.00 & $0.00 \mathrm{~d}$ & 0.00 & - \\
\hline 2 & 3.15 & $3.70 \mathrm{a}$ & 4.00 & 3.80 & $4.30 \mathrm{a}$ & 5.00 & $P=0.25$ \\
\hline 4 & 3.00 & $3.00 \mathrm{a}$ & 3.70 & 3.50 & $4.00 \mathrm{a}$ & 4.15 & $P=0.17$ \\
\hline 6 & 3.50 & $3.70 \mathrm{a}$ & 4.00 & 2.70 & $3.70 \mathrm{a}$ & 4.85 & $P=0.80$ \\
\hline 8 & 2.50 & $2.70 \mathrm{~b}$ & 3.00 & 2.50 & $3.00 \mathrm{~b}$ & 3.30 & $P=0.56$ \\
\hline 12 & 2.30 & $2.30 \mathrm{~b}$ & 2.30 & 2.00 & $2.30 \mathrm{c}$ & 2.85 & $P=1.00$ \\
\hline 24 & 1.70 & $1.70 \mathrm{c}$ & 2.00 & 2.00 & $2.00 \mathrm{c}$ & 2.15 & $P=0.23$ \\
\hline 36 & 1.15 & $1.70 \mathrm{c}$ & 2.00 & 1.70 & $1.70 \mathrm{c}$ & 2.15 & $P=0.33$ \\
\hline 48 & 0.50 & $1.30 \mathrm{c}$ & 1.65 & 1.00 & $1.30 \mathrm{c}$ & 1.50 & $P=0.60$ \\
\hline 72 & 0.00 & $0.00 \mathrm{~d}$ & 0.80 & 0.30 & $0.70 \mathrm{~d}$ & 1.00 & $P=0.18$ \\
\hline P-value & \multicolumn{3}{|c|}{$P<0.01$} & \multicolumn{3}{|c|}{$P<0.01$} & \\
\hline \multicolumn{8}{|c|}{ UMPS } \\
\hline \multirow{2}{*}{ Times } & \multicolumn{3}{|c|}{ GC } & \multicolumn{3}{|c|}{ GV } & \\
\hline & $\mathrm{Q}_{1}$ & Median & $\mathrm{Q}_{3}$ & $\mathrm{Q}_{1}$ & Median & $\mathrm{Q}_{3}$ & $P$-VALUE \\
\hline Basal & 2.00 & $2.00 \mathrm{~b}$ & 2.25 & 2.00 & 2.00 & 2.00 & $P=0.49$ \\
\hline 2 & 3.58 & $4.85 \mathrm{a}$ & 5.18 & 2.00 & 2.35 & 3.33 & $P=0.06$ \\
\hline 4 & 2.70 & $3.85 \mathrm{a}$ & 4.78 & 1.53 & 2.65 & 4.03 & $P=0.25$ \\
\hline 6 & 3.60 & $4.00 \mathrm{a}$ & 4.78 & 1.98 & 2.50 & 2.70 & $P=0.01$ \\
\hline 8 & 2.05 & $2.80 \mathrm{~b}$ & 3.85 & 2.70 & 3.00 & 3.50 & $P=0.31$ \\
\hline 12 & 1.83 & $2.00 \mathrm{~b}$ & 2.55 & 1.60 & 1.70 & 2.08 & $P=0.34$ \\
\hline 24 & 1.00 & $1.80 \mathrm{~b}$ & 2.78 & 2.05 & 2.30 & 2.78 & $P=0.40$ \\
\hline 36 & 1.30 & $1.65 \mathrm{~b}$ & 2.25 & 1.23 & 2.00 & 3.00 & $P=0.83$ \\
\hline 48 & 1.00 & $1.00 \mathrm{~b}$ & 1.48 & 1.00 & 2.00 & 2.78 & $P=0.24$ \\
\hline 72 & 1.00 & $1.85 \mathrm{~b}$ & 2.50 & 1.53 & 2.00 & 2.18 & $P=0.79$ \\
\hline$P$-value & \multicolumn{3}{|c|}{$P<0,01$} & \multicolumn{3}{|c|}{$P=0.10$} & \\
\hline \multicolumn{8}{|c|}{ CMPS-SF } \\
\hline \multirow{2}{*}{ Times } & \multicolumn{3}{|c|}{ GC } & \multicolumn{3}{|c|}{ GV } & \multirow[b]{2}{*}{$P$-value } \\
\hline & $\mathrm{Q}_{1}$ & Median & $\mathrm{Q}_{3}$ & $\mathrm{Q}_{1}$ & Median & $\mathrm{Q}_{3}$ & \\
\hline Basal & 0.00 & $0.00 \mathrm{c}^{*}$ & 0.00 & 0.00 & $0.00 \mathrm{c}$ & 0.00 & - \\
\hline 2 & 1.70 & $2.00 \mathrm{a}$ & 3.15 & 1.85 & $2.00 \mathrm{a}$ & 3.00 & $P=0.95$ \\
\hline 4 & 1.50 & $2.00 \mathrm{a}$ & 2.65 & 1.15 & $1.30 \mathrm{~b}$ & 1.45 & $P=0.12$ \\
\hline 6 & 1.30 & $2.00 \mathrm{a}$ & 2.15 & 1.15 & $1.30 \mathrm{~b}$ & 1.30 & $P=0.29$ \\
\hline 8 & 0.85 & $1.00 \mathrm{~b}$ & 1.35 & 1.00 & $1.30 \mathrm{~b}$ & 1.30 & $P=0.51$ \\
\hline 12 & 1.00 & $1.00 \mathrm{~b}$ & 1.00 & 0.50 & $1.00 \mathrm{~b}$ & 1.30 & $P=0.79$ \\
\hline 24 & 0.50 & $0.70 \mathrm{~b}$ & 1.00 & 0.00 & $0.00 \mathrm{c}$ & 0.50 & $P=0.09$ \\
\hline 36 & 0.45 & $0.70 \mathrm{~b}$ & 0.85 & 0.00 & $0.00 \mathrm{c}$ & 0.00 & $P<0.01$ \\
\hline 48 & 0.30 & $0.30 \mathrm{c}$ & 0.65 & 0.00 & $0.00 \mathrm{c}$ & 0.00 & $P<0.01$ \\
\hline 72 & 0.00 & $0.00 \mathrm{c}$ & 0.30 & 0.00 & $0.00 \mathrm{c}$ & 0.00 & $P=0.07$ \\
\hline$P$-value & & $P<0.01$ & & & $P<0.01$ & & \\
\hline
\end{tabular}

Figure 1. The medians and the first and third quartiles of the average total scores of female dogs who underwent two-port laparoscopic-assisted (GV) or conventional (GC) $\mathrm{OVH}$ at different time points, using the Visual Analogue (VAS), the University of Melbourne (UMPS), and the short form of the Glasgow Composite Measure (CMPSSF) pain scales; "d," "b," and "c" indicate the baseline values of VAS, UMPS, and CMPS-SF, respectively. 

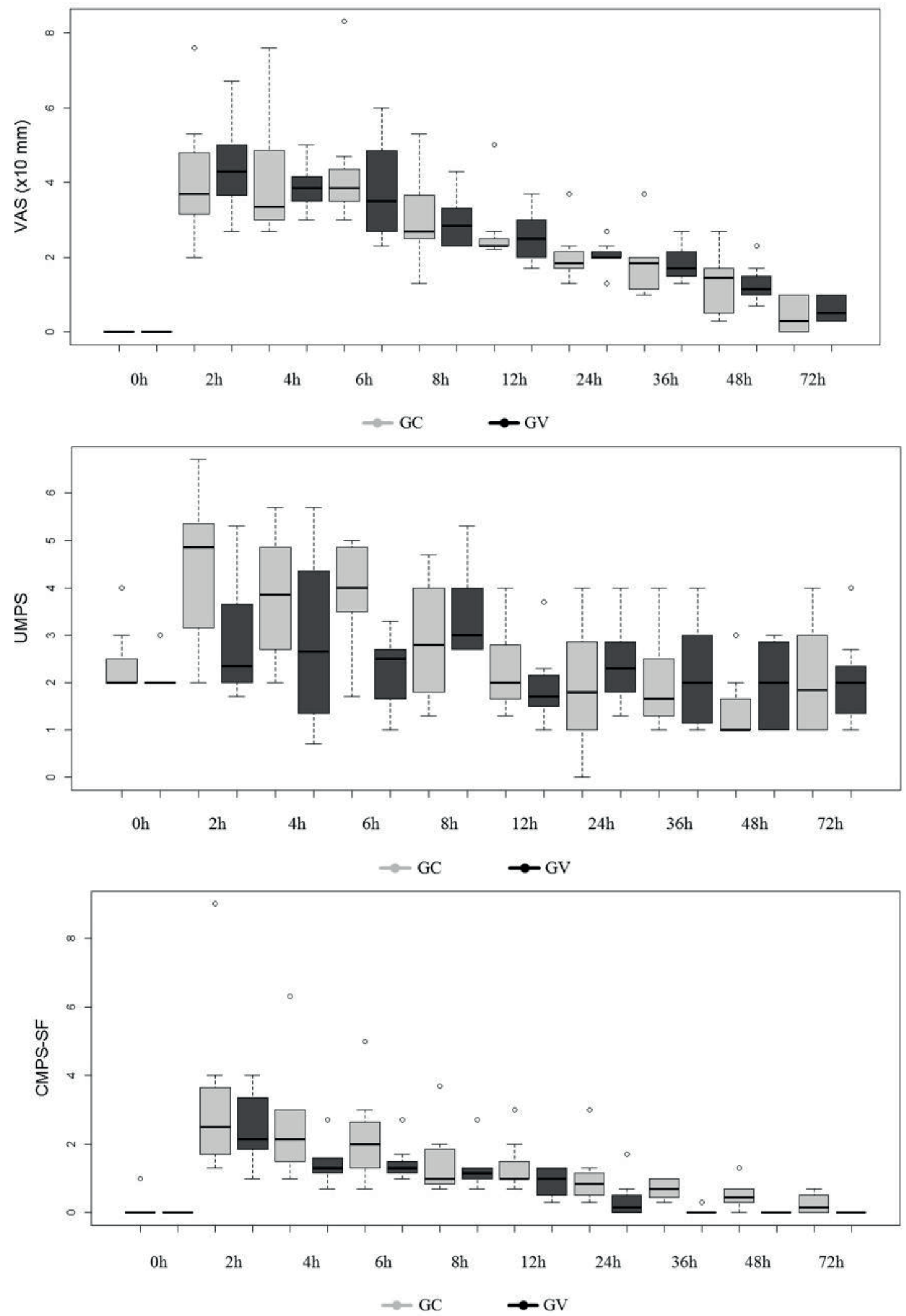

Figure 2. Boxplots of the medians and the first and third quartiles of the average total scores of female dogs who underwent the two-port laparoscopic-assisted (GV) or conventional (GC) OVH. Values are presented at different time points according to the Visual Analogue Scale (VAS), the University of Melbourne (UMPS), and the short form of the Glasgow Composite Measure (CMPS-SF) pain scales. 
The UMPS takes into consideration physiological and behavioral parameters related to pain, which increases the scale's sensibility and specificity (Gaynor, 2009). The UMPS consists of six broad categories (physiological data, response to palpation, activity, mental status, posture, and vocalization), each of which is divided into three or more levels and assigned a different numerical weight. For the six categories, the patient was evaluated for each parameter by a score ranging from 0 (without pain) to 3 (highest pain). Twenty-seven points was considered the most painful condition for this scale (Wiese, 2014). There was a difference between the baseline scores and those at 2, 4, and $6 \mathrm{~h}$ after $\mathrm{GC}$, as verified by the VAS assessment. In the GV group, there was no difference at any time point. Significant differences between the groups occurred at $6 \mathrm{~h}$ (Figure 1 and Figure 2) $(P=0.02)$, when the GV group received lower scores. Although Devitt, Cox and Hailey (2005) found that conventional $\mathrm{OVH}$ resulted in significantly higher pain at most time points compared to the two-port laparoscopicassisted technique, we would argue that the efficacy of our analgesic protocol led to the different results in our study. The correlation between the evaluators $(1 \times 2,2 \times 3$, and $1 \times 3)$ was strong $(r=0.88,0.89$, and 0.84 , respectively) (Santos, 2018).

The CMPS is a behavior-based composite scale used to assess acute pain in dogs. The CMPSSF limits the interpretation of the behavior, the subjectivity, and the variability of the evaluator, which thus increases the accuracy of the observed scores. Scoring ranges from 0 to 24 points, with higher scores indicating greater postoperative pain (Wiese, 2014). Using the CMPS-SF, the GC group had higher assessment scores at 2, 4, and $6 \mathrm{~h}$ than it had at baseline, similar to the results of the VAS and UMPS assessments. These values decreased at 8 and $12 \mathrm{~h}$, and returned to baseline by $48 \mathrm{~h}$. For the $\mathrm{GV}$ group, pain increased at $2 \mathrm{~h}$ but decreased at 4 , 6,8 , and $12 \mathrm{~h}$, returning to baseline by $24 \mathrm{~h}$. Pain scores were significantly lower in the GV group at 36 and $48 \mathrm{~h}(P<0.01)$ (Figure 1 and Figure 2).
It is possible that the scale's high sensitivity was responsible for the major difference observed between groups. Moderate correlation was verified between the evaluators $(r=0.52,0.68$, and 0.65$)$.

One significant difference between the groups in regards to the time to the first spontaneous food intake $(P=0.01)$ was that it occurred earlier in the GV group $(2.85 \pm 1.57 \mathrm{~h})$ compared to the GC group $(7.14 \pm 3.23 \mathrm{~h})$. This may be associated with the idea that videosurgery promotes early recovery, which has been suggested by Davidson, Moll and Payton (2004), Hancock et al. (2005), and Linhares et al. (2019). However, after comparing the time to the first defecation between the groups, no significant difference was found $(P=0.14, \mathrm{GV}=14.86 \pm 11.48$ $\mathrm{h}$ vs $\mathrm{GC}=24 \pm 11.05 \mathrm{~h}$ ). This difference may not have been observed in our study because of the satisfactory analgesic protocol, corroborating the findings of Lamont and Tranquilli (2000), who found that controlled pain minimally affects intestinal and bladder tonus, maintaining normal function of the gastrointestinal and urinary tract.

Dipyrone has previously been described as an analgesic for dogs after OVHs (Imagawa et al., 2011). Meloxicam has also been used to treat pain (Caulkett et al., 2003), however, its association with $\mathrm{N}$-butylescopolamine has not been investigated. In our study, rescue analgesics were predicted when $30 \%$ of the scales' maximum scores were reached. This study's medication protocol was considered effective in controlling pain following both $\mathrm{OVH}$ techniques, because no rescue analgesia was required at any time point, in contrast to other studies (Davidson et al., 2004; Devitt et al., 2005). Although videosurgery is considered a less painful and less invasive surgical technique than a celiotomy (Brun, 2015; Freeman et al., 2010), the authors believe that the difference between the techniques was minimal because the analgesic protocol used was effective for pain control in this study.

The precise etiology of pain following laparoscopic surgery remains unclear. It is known 
that postoperative pain is multifactorial, divided into parietal and visceral pain (Elhakim, Elkott, Ali, \& Tahoun, 2000). Open celiotomies result in increased parietal pain due to surgical access (Kim et al., 2012), visceral exposition, desiccation (Devitt et al., 2005), and visceral handling (Kim et al., 2012). During a laparoscopy, phrenic neuritis occurs from the compression of the diaphragm as a result of $\mathrm{CO}_{2}$ pneumoperitoneum, peritoneal fluid acidosis, and mechanoreceptors of the visceral smooth muscles (A $\delta$ and C) responsible for the tension applied to the peritoneum (Lamont \& Tranquili, 2000). Additionally, direct trauma to vessels, traction on nerves, and inadvertent sudden peritoneal distention may cause pain during laparotomies (Ganem et al., 2005).

It has been hypothesized that bipolar cauterization and transection of the ovarian pedicle during laparoscopic surgery produces less pain than pulling the ovarian pedicle and tearing the suspensory ligament during conventional surgery, which causes peritoneal detachment and retroperitoneal hematoma (Devitt et al., 2005). In the current study, the suspensory ligament was torn digitally in the GC group to promote exposition and ligation of the ovarian pedicles, while in the GV group it was not necessary.

$\mathrm{OVH}$ causes pain independent of the surgical technique, which may vary according to the trauma and individual pain threshold (Caulkett et al., 2003). Despite the longer surgical time for the GV group $(P=0.01, \mathrm{GV}=32.14 \pm 7.96 \mathrm{~min}$ vs $\mathrm{GC}$ $=21.86 \pm 3.71 \mathrm{~min})$, their first spontaneous food intake occurred earlier than those who underwent the conventional OVH. Surgical time could be affected by the hemostatic technique, intraoperative complications, the prior experience of the surgeon, and the patient's clinical status (Dutta, Maiti, Ajith, $\&$ Kumar, 2010). In the current study, the absence of an adequate surgical table indicated for laparoscopy affected surgical time. Nevertheless, electrosurgery requires less surgical time during laparoscopic procedures (Devitt et al., 2005).
Two animals from the GC group had postoperative emesis. One patient vomited at 2 and 36 hours following surgery, and the other presented with biliary vomiting ( $1 \mathrm{hr}$ and $3 \mathrm{hr}$ ). The owners reported no changes following hospital discharge. Nausea, vomiting, diarrhea, and abdominal distention are commonly associated with postoperative pain. Although not very common, vomiting may occur in the first $6 \mathrm{~h}$ postoperatively in animals that are given isoflurane anesthesia (Imagawa et al., 2011). Moreover, NSAIDs may cause emesis since they affect the metabolism of arachidonic acid by blocking COX-1, which regulates the secretion of protective mucus in the gastrointestinal tract (Caulkett et al., 2003). Although there were transient episodes, further investigations are required to assess gastrointestinal changes conferred by this analgesic regimen.

This study's analgesic protocol was effective in controlling pain after conventional or twoport laparoscopic-assisted OVH. The animals that underwent the laparoscopic-assisted technique presented faster recovery than those who underwent the conventional surgery.

\section{Acknowledgements}

The authors would like to thank WEM Equipamentos Eletrônicos Ltda (Ribeirão Preto, Brazil) and Lina Medical Inc. (Denmark) for providing the Lina Tripol Powerblade 5-mm diameter, 42-cm length laparoscopic bipolar forceps used for laparoscopic-assisted OVH.

\section{References}

Brun, M. V. (2015). Cirurgias do aparelho reprodutor feminino de caninos. In Brun, M. V. (Ed.), Videocirurgia em pequenos animais (pp. 186-213). Rio de Janeiro: Roca.

Caulkett, N., Read, M., Fowler, D., \& Waldnert, C. A. (2003). A comparison of the analgesic effects of butorphanol with those of meloxicam after elective ovariohysterectomy in dogs. Canadian Veterinary 
Journal, 44(7), 565-570. Retrieved from https:// www.ncbi.nlm.nih.gov/pmc/articles/PMC340207/

Chandrasekharan, N. V., Dai, H., Roos, K. L., \& Evanson, N. K. (2002). COX-3, a cyclooxygenase-1 variant inhibited by acetaminophen and other analgesic/ antipyretic drugs: Cloning, structure, and expression. Proceedings of the National Academy of Sciences, 99(21), 13926-13931. doi: 10.1073/pnas.162468699 Retrieved from https://www.ncbi.nlm.nih.gov/ pubmed/12242329

Davidson, E. B., Moll, H. D., \& Payton, M. E. (2004). Comparison of laparoscopic ovariohysterectomy and ovariohysterectomy in dogs. Veterinary Surgery, 33(1), 62-69. doi: 10.1111/j.1532-950x.2004.04003.x

Devitt, C. M., Cox, R. E., \& Hailey, J. J. (2005). Duration, complications, stress, and pain of open ovariohysterectomy versus a simple method of laparoscopic-assisted ovariohysterectomy in dogs. Journal of American Veterinary Medical Association, 227(6), 921-927. doi: 10.2460/javma.2005.227.921

Dutta, A., Maiti, S. K., Ajith, P., \& Kumar, N. (2010). Evaluation of different laparoscopic sterilization techniques in a canine birth control program. Turkey Journal Veterinary Animal Science, 3(4), 393-402. doi: 10.3906/vet-0908-24

Elhakim, M., Elkott, M., Ali, N. M., \& Tahoun, H. M. (2000). Intraperitoneal lidocaine for postoperative pain after laparoscopy. Acta Anaesthesiologica Scandinavica, 44(3), 280-284. doi: 10.1034/j.13996576.2000.440310.x

Flôr, P. B. (2012). Avaliação da dor. In D. Fantoni (Ed.), Tratamento da dor na clínica de pequenos animais (pp. 81-92). São Paulo: Elsevier.

Freeman, L. J., Rahmani, E. Y., Al-Haddad, M., Sherman, S., Chiorean, M. V., Sslzer, D. J.,... Constable, P. D. (2010). Comparison of pain and postoperative stress in dogs undergoing natural orifice transluminal endoscopic surgery, laparoscopic, and open oophorectomy. Gastrointestinal Endoscopy, 72(2), 373-380. doi: 10.1016/j.gie.2010.01.066

Ganem, E. M., Salem, I. C. F., Fukushima, F. B., Nakamura, G., Dias, R., Fontana, A. L., \& Leite, N. J. (2005). Eficácia da N-butilescopolamina e dipirona sódica associadas ao cetoprofeno no alívio da dor pós-operatória de pacientes submetidas a duas técnicas diferentes de laqueadura por laparoscopia. Revista Brasileira de Anestesiologia, 55(4), 397404. doi: 10.1590/S0034-70942005000400004. Recuperado de http://www.scielo.br/pdf/rba/v55 n4/ en_v55n4a04.pdf
Gaynor, J. S. (2009). Other drugs used to treat pain. In J. S. Gaynor, \& W. W. Muir (Eds.), Handbook of veterinary pain management (pp. 260-279). Saint Louis: Elsevier.

Hancock, R. B., Otto, I., Waldron, D. R., Duncan, R. B., Broadstone, R. V., \& Hendrix, P. K. (2005). Comparison of postoperative pain after ovariohysterectomy by harmonic scalpel-assisted laparoscopy compared with median celiotomy and ligation in dogs. Veterinary Surgery, 34(3), 273-282. doi: 10.1111/j.1532-950X.2005.00041.x

Hansen, B. D. (2003). Assessment of pain in dogs: veterinary clinical studies. Institute for Laboratory Animal Research Journal, 44(3), 197-205. doi: 10.1093/ilar.44.3.197

Imagawa, H. V., Fantoni, D. T., Tatarunas, A. C., Mastrocinque, S., Aalmeida, T. F., Ferreira, F., \& Posso, I. P. (2011). The use of different doses of metamizol for post-operative analgesia in dogs. Veterinary Anaesthesia and Analgesia, 38(4), 385393. doi: 10.1111/j.1467-2995.2011.00617

Kim, Y. K., Lee, S. S., Suh, E. H., Lee, L., Lee, H. C., Lee, H. J., \& Yeon, S. C. (2012). Sprayed intraperitoneal bupivacaine reduces early postoperative pain behavior and biochemical stress response after laparoscopic ovariohysterectomy in dogs. Veterinary Journal, 191(2), 188-192. doi: 10.1016/j. tvj1.2011.02.013

Lamont, L. A., \& Tranquili, W. J. (2000). Physiology of pain. Veterinary Clinics of North American Small Animal Practice, 30(4), 703-728. doi: 10.1016/ s0195-5616(08)70003-2

Linhares, M. T., Feranti, J. P. S., Coradini, G. P., Martins, L. R., Martins, A. R., Sarturi, V. Z.,... Brun, M. B. (2019). Canine ovariectomy by hybrid or total natural orifice transluminal endoscopic surgery: technical feasibility study and pain assessment. Veterinary Surgery, 48(47), O74-082. doi: 10.1111/ vsu. 12900

Macphail, M. C., \& Fossum, T. W. (2019). Surgery of the reproductive and genital systems. In T. W. Fossum (Ed.), Small animal surgery (pp. 720-787). Philadelphia, PA: Elsevier.

Murrell, J. C., Psatha, E. P., Scott, E. M., Reid, J., \& Hellebrekers, L. J. (2008). Application of a modified form of the Glasgow pain scale in a veterinary teaching centre in the Netherlands. The Veterinary Record, 162(13), 403-408. doi: 10.1136/ vr.162.13.403 
R Development Core Team (2018). A language and environment for statistical computing. R Foundation for Statistical Computing. Vienna: R Foundation for Statistical Computing.

Rialland, P., Authier, S., Guillot, M., Del Castillo, J. R. E., Veilleux-Lemieux, D., Frank, D.,.. Troncy, E. (2012). Validation of orthopedic postoperative pain assessment methods for dogs: a prospective, blinded, randomized, placebo-controlled study. Plos One, 7(49480), 1-10. doi: 10.1371/journal.pone.0049480
Santos, C. (2018). Distribuições bidimensionais - correlações. In Santos, C., Manual de autoaprendizagem - estatística descritiva (pp. 125-156). Lisboa: Edições Sílabo.

Wiese, A. J. (2014). Assessing pain. In J. S. Gaynor, \& W. W. Muir (Eds.), Handbook of veterinary pain management (pp. 67-96). Saint Louis: Elsevier Mosby. 